\title{
急然
}

\section{プラズマ吸収プローブによる プロセスプラズマの電子密度測定}

\author{
菅 井 秀 郎 \\ (名古屋大学大学院工学研究科)
}

\section{Plasma A bsorption Probe Measurement of Electron Density of Processing Plasmas}

\author{
SU GA I Hideo
}

Graduate School of Engineering, Nagoya University, Nagoya 464-8603, Japan

(Received 2 A ugust 2002)

\begin{abstract}
T his paper review s a novel and simple technique for measuring electron density using a plasma absor ption probe (PA P). T he PA P enables the measurement of local absolute electron density ev en when the probe surface is soiled with processing plasmas. T he technique relies on the absor ption of surface waves (SW s) resonantly excited around the probe head at critical frequencies which depend on the electron density.T he PA P consists of a small antenna connected to a coaxial cable and is enclosed in a tube of dielectric constant $\varepsilon_{\mathrm{d}}$ inserted in a plasma of electron plasma frequency $\omega_{\mathrm{p}}$. A netw ork analy zer feeds a rf signal to the antenna and displays the frequency dependence of the pow er absorption. A series of resonant absorptions is observed at frequencies slightly above the SW resonance frequency, $\omega_{\mathrm{SW}}=\omega_{\mathrm{p}} /\left(1+\varepsilon_{\mathrm{d}}\right)^{1 / 2}$, w hich allow s us to determine the electron density. T y pical examples of measured PA P data and future challenges are presented.
\end{abstract}

Keywords:

plasma absor ption probe, electron density, surface wave, Langmuir probe, reactive plasma

\section{1 ・はじめに}

近年 , プラズマ技術を用いる半導体プロセスが高度化 するにつれて, 研究開発および生産現場におけるプラズ マモニタリングの重要性が高まっている．プラズマを特 徵づける樣々なパラメータの中で, 電子密度は最も基本 的な物理量であり，重要な知見を与える．乥れにもかか わらず, 実際のリアクター内で種々のガスから生成され る反応性プラズマの電子密度を, ユニバーサルに再現性 よく測定する手段はなかなか見当たらないのか現状であ る。

電子密度を測定する簡便な方法として, 昔から静電探 author'se-mail:sugai@nuee.nagoya-u.ac.jp
針法 (ラングミュアプローブ法) が用いられてきた .し かし，反応性プラズマ中にプローブを挿入すると，金属 プローブ表面が絶縁性の薄膜で覆われてしまい, 測定不 能に陥ることが多いのはよく知られている．弚のような 場合にも適用できる方法として，マイクロ波干渉計があ るが , 装置が大掛かりになるとともに , マイクロ波の伝 搬路に沿った平均密度しか得られない．類似の方法にマ イクロ波反射計があるが，プロセスプラズマは低密度な のでアンテナが大きくなり，観測ポートやプラズマサイ ズが小さいなどの問題が出てくる .

弚の点, プラズマ振動法[1-5]は空間分解能もあるが， 
フィラメントを用いているため金属污染や寿命の問題が ある.一方,絶縁したプローブにパルス電圧を印加して， 光の応答特性からプラズマパラメータを求める提案がな されている[6] .また, 容器壁の位置に設けた $1 \mathrm{~mm}^{2}$ 程度 の浮遊電位の電極に RF バイアスを短くバース卜的に加 え，弚のRF が切れた後に負の自己バイアスに向かって 流れるイオン電流をモニタして , プロセスを監視する試 みか報告されている[7] .

しかし，いずれも得られる情報や適用範囲が限られて いる。最近，我々は精度よく簡単に電子密度測定する新 規な方法として，プラズマ吸収プローブ (PAP : Plasma A bsorption Probe) を開発した[8 14] .この方法の原理 は, 周波数掃引しながら微少マイクロ波信号をプローブ 頭部に送り，共鳴的に吸収が起こる周波数を測定して， 谷の值から電子密度を求めるものである.すなわち，プ ローブ頭部における表面波[15]の共鳴的な励起と吸収を 利用する新しい原理に基づいている．乥の最大の利点 は, プローブに絶縁膜がついても安定に電子密度を測定 できることにあり，弚の他にも，金属污染をもたらさな いことや，広範囲 $\left(10^{15}-10^{19} \mathrm{~m}^{-3}\right)$ の電子密度を時間 · 空間分解して測定できるなどの特色がある .このプラズ マ吸収プローブ法の開発状況や今後の課題について解説 する .

\section{2 .プローブの構造と吸収周波数}

プラズマ吸収プローブの計測システムは, ガラス管と 同軸ケーブルとネットワークアナライザを用意すれば自 分でも簡単に作りあげることができる[8] .F ig.1は光の システムの例を示している.頭部を封じた細い誘電体 チューブ (材質はパイレックス，石英，セラミック等) を プラズマ容器内に入れる .チューブ内は大気圧であり， 光の中に外から同軸ケーブルを挿入し，ケーブル先端の 中心導体をアンテナとして使用する . このアンテナに， ネットワークアナライザから $1 \mathrm{~mW}$ 程度の微小なパワー を, 周波数 $0.3 \mathrm{MHz}$ から $3 \mathrm{GHz}$ の範囲で変化しながら送 信する. 弚の結果 , アンテナの周りの電磁界によって, プラズマと誘電体チューブとの界面に表面波が励起され る，後で述べるように，電子密度で決まるある条件を満 足する周波数になったとき, プローブ頭部に強い定在波 が共鳴的に立つ .このとき，アンテナから反射されても どってくるパワーが減少する．逆に言えば，アンテナに 送ったパワーが共鳴的にプラズマに吸収される．弚の吸 収周波数から電子密度を求めることができる．プローブ のサイズの例をあげると，石英管(比誘電率 $\varepsilon_{\mathrm{d}}=3.78$ )の

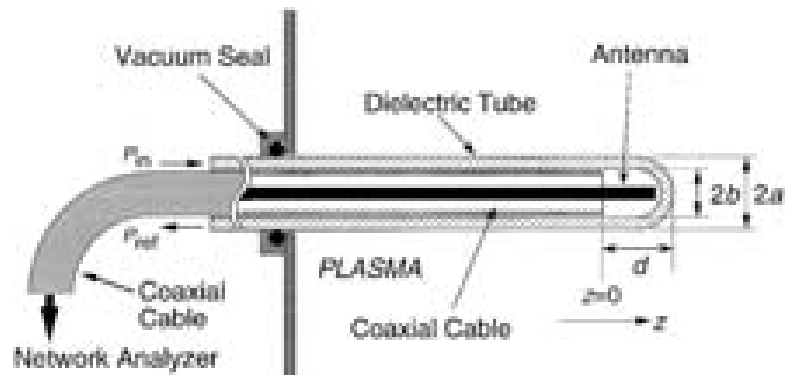

Fig. 1 Plasma absorption probe system.

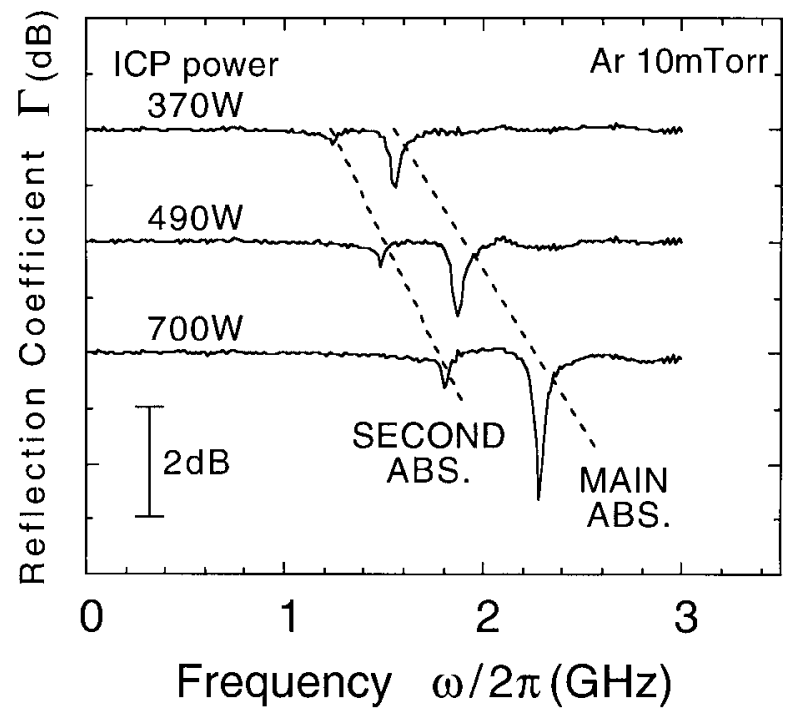

Fig. 2 Reflection coefficient $\Gamma$ vs. frequency $\omega / 2 \pi$ for different ICP powers.

外径が $2 a=2-6 \mathrm{~mm}, 50 \Omega$ セミリジットケーブルの先端 のアンテナ長が 3 $5 \mathrm{~mm}$ ，プローブ頭部の長さは $d=4$ 〜12 $\mathrm{mm}$ である .

ネットワークアナライザは , アンテナへの入射パワー $P_{\text {in }}$ と反射されてくるパワー $P_{\text {ref }}$ の比を測定して , 弚の対 数値 $\Gamma=\log \left(P_{\mathrm{ref}} / P_{\mathrm{in}}\right)$ として定義される反射係数を，掃 引周波数 $\omega / 2 \pi$ の関数として表示する機能をもっている Fig.2は，光のようにしてネットワークアナライザに よって測定された反射係数のスペクトルの例を示してい る .この測定において注意すべきことは , プラズマの有 無によらず，アンテナ端から強い反射があり，これがプ ラズマのみによるパワー吸収効果の測定を阻害する点で ある．乥こで，この伝送線路上の反射効果を除くため， プラズマなしで予め測定した反射係数 $\Gamma_{0}=\rho_{0} \exp \left(i \theta_{0}\right)$ を用いて，プラズマ有りの状態のデータ $\Gamma_{\mathrm{p}}=\rho_{\mathrm{p}} \exp$ $\left(i \theta_{\mathrm{p}}\right)$ を割算して $\Gamma=\Gamma_{\mathrm{p}} / \Gamma_{0}$ を求め, 光の対数值 $\log |\Gamma|=$ 
$\log \rho_{\mathrm{p}}-\log \rho_{0}$ をネットワークアナライザに表示させ る.このようにしてほぼプラズマだけの吸収効果を抽出 した結果が，Fig. 2 に示す吸収スペクトルである.この データは,アルゴン $10 \mathrm{mT}$ orr の誘導結合プラズマ(ICP) の放電パワーを変えた例である . 同一パワーにおいて大 小 $2 つ の$ 吸収スペクトルが見られ , パワーとともに電子 密度が増加すると吸収周波数が高くなることがわかる． このように，しばしば複数の吸収スペクトルか現れるの は，後で説明するように，アンテナ線がプローブ中心軸 からずれていることによる非軸対称性のためと考えられ る。

Fig.1の構造からわかるように, 誘電体チューブ内は 大気圧であり，外から同軸ケーブルを容易に出し入れす ることができる．すなわち，同図に示すプローブ頭部の 長さdを変えることができる. 乥こで, 吸収周波数が $d$ に対してどう変化するかを調べた例が , Fig.3である . これより， $d$ が小くなるにつれて吸収周波数が低くな り,$d \rightarrow 0$ の極限では複数本の吸収スペクトルがすべて， ある一定の周波数 $\left(\omega_{\mathrm{sw}} / 2 \pi\right)$ に近づくように見える．これ らの振る舞いは, 次に述べる表面波の性質によるもので ある

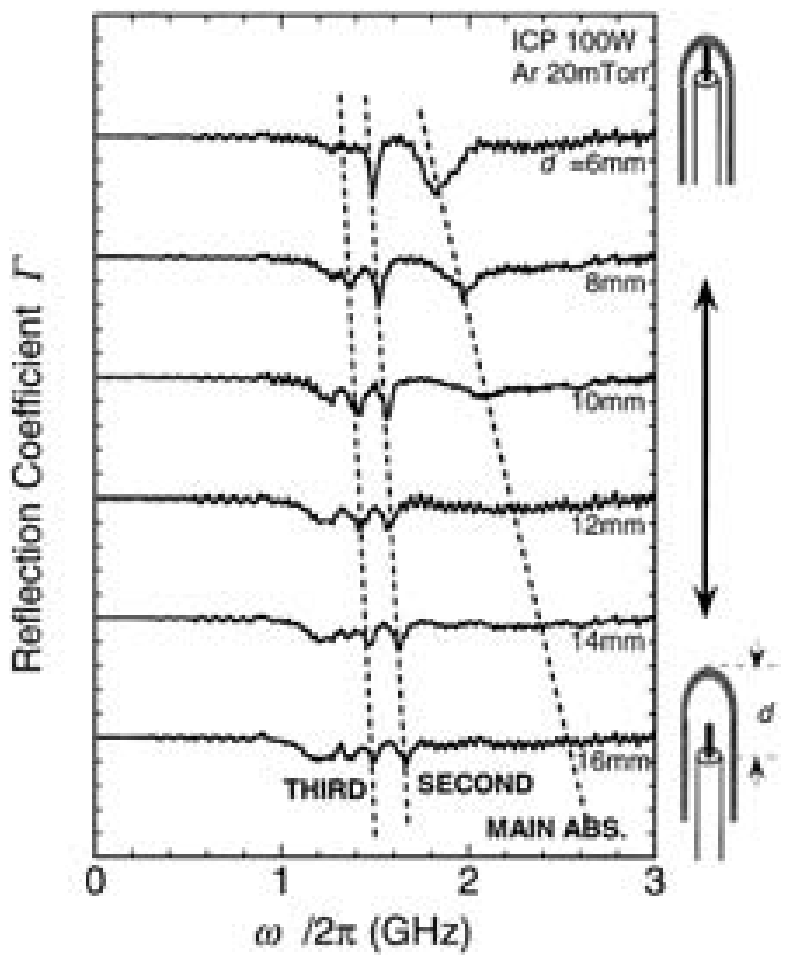

Fig. 3 Absorption frequency spectra for different values of probe head length $d$ in the same conditions of 100 W ICP at 20 mTorr argon.

\section{3. 表面波の分散関係}

2つの媒質か接しているとき，弚の境界面に沿って伝 わる波を一般に表面波と呼引゙ . Fig.1に示すプラズマ吸 収プローブの場合 , 誘電体チューブはプラズマ媒質と接 しており，条件が整えば㫕の界面に沿って表面波が伝搬 できる . 同図のアンテナ近傍のプローブ頭部は , 誘電体 チューブの内部が空気, 外部がプラズマで両たされてい る.乥こでFig.4のように,$z$ 軸に沿う無限に長い誘電体 チューブ(外径 $2 a ，$ 内径 $2 b$ ) が均一なプラズマ中にある 場合を考えると，同図の右端に示すように，波の電界強 度 $|E|$ が界面 $r=a$ で最大となるような表面波が存在す る . 厳密には, プラズマと誘電体の間にシースが形成さ れるが, 兴の厚さが $a$ に比べて十分に薄くて無視できる 場合を考える(シースの影響については後述)．また，ア ンテナ導体は細いとして無視し, 誘電体チューブ内は真 空とみなす .この Fig.4のモデルにおいて , 冷たいプラ ズマの比誘電率 $\left(1-\omega_{\mathrm{p}}^{2} / \omega^{2}\right)$ を用いて静電近似のもとに 波動を扱う. 円筒座標 $(r, \theta, z)$ を用いて, $r$ 方向の振幅 $A(r), \theta$ 方向のモード数 $m, z$ 方向の波数 $\beta=2 \pi / \lambda(z$ 方向の波長 $\lambda)$ をもつ角周波数 $\omega$ の波動を $A(r) \exp [\mathrm{i} m \theta+\mathrm{i}(\beta z-\omega t)]$ の形に表す $. r=a, b$ におけ る電磁界の境界条件を適用すれば，次のような波の分散 式が得られる [文献 8 の Eq.(1)のミスプリントを修正し た式] .

$$
\left[1-\left(\frac{\omega_{\mathrm{p}}}{\omega}\right)^{2}\right] \frac{1}{\epsilon_{\mathrm{d}}}=\frac{\mathrm{K}_{m}(\beta a)}{\mathrm{K}_{m}^{\prime}(\beta a)} \cdot \frac{f \cdot \mathrm{I}_{m}^{\prime}(\beta a)+g \cdot \mathrm{K}_{m}^{\prime}(\beta a)}{f \cdot \mathrm{I}_{m}(\beta a)+g \cdot \mathrm{K}_{m}(\beta a)}
$$

$$
\begin{aligned}
\text { ここに } & f=\mathrm{I}_{m}(\beta a)\left[\varepsilon_{\mathrm{d}} \mathrm{I}_{m}(\beta b) \mathrm{K}_{m}^{\prime}(\beta b)-\mathrm{I}_{m}^{\prime}(\beta b) \mathrm{K}_{m}(\beta b)\right] \\
& g=\left(1-\varepsilon_{\mathrm{d}}\right) \mathrm{I}_{m}^{\prime}(\beta b) \mathrm{I}_{m}(\beta b)
\end{aligned}
$$

また $\mathrm{I}_{m}$ と $\mathrm{K}_{m}$ は $m$ 次の第 1 種と第 2 種の变形ベッセル

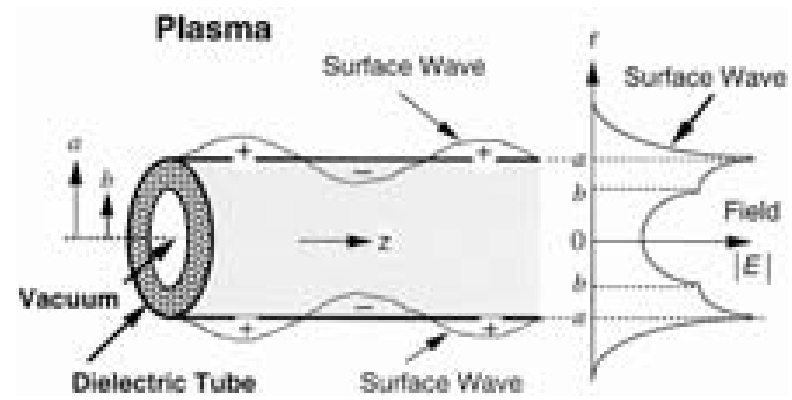

Fig. 4 Surface wave propagation along cylindrical dielectric tube immersed in plasma. 
関数であり, $\mathrm{I}_{m}^{\prime}$ と $\mathrm{K}_{m}^{\prime}$ は光れらの変数による微分を示す .

$z$ 方向の波長 $\lambda$ が無限に小さくなる極限(すなわち, 波 数 $\beta$ が無限大となる表面波の共鳴条件) では, 上式 (1) の右辺は- 1 に近づくので, 光のとき左辺から次式の表 面波共鳴周波数が得られる.

$$
\omega_{\mathrm{sw}}=\frac{\omega_{\mathrm{p}}}{\sqrt{1+\varepsilon_{\mathrm{d}}}}
$$

$\omega$ がこの共鳴周波数より高いとき,軸対称モードの $m=0$ をはじめとして , 非対称モードの $m=1,2, \cdots$ と無 限の固有モードの表面波の伝搬が可能となる .Fig.5の 3 本の実線のカーブは, $a=3 \mathrm{~mm}, b=2 \mathrm{~mm}, \varepsilon_{\mathrm{d}}=3.78$ の石英管の場合に，式(1)を解いて得られた規格化周波 数 $\omega / \omega_{\mathrm{p}}$ と波長 $\lambda$ の関係を, 方位角モード数 $m=0,1,2$ に対して示した分散曲線である。

これまでは，Fig.1におけるアンテナ近傍のプローブ 頭部の表面波を考えてきた .一方 , アンテナより左側の 同軸ケーブルで両たされた領域の誘電体チューブとプラ ズマとの界面においても表面波が伝搬できる .このとき の分散関係も，上と同樣にして求めることができる．す なわち, 同軸ケーブルは接地導体で覆われているので， これを金属円柱とみなし，Fig.4の $r<b$ の領域を真空の かわりに金属でおきかえる .このモデルを用いて，表面 波の分散式が次のように得られる .

$$
\begin{aligned}
\left(1-\frac{\omega_{\mathrm{p}}^{2}}{\omega^{2}}\right) & \frac{1}{\varepsilon_{\mathrm{d}}}=\frac{\mathrm{K}_{m}(\beta a)}{\mathrm{K}_{m}^{\prime}(\beta a)} \\
& \cdot \frac{\mathrm{I}_{m}^{\prime}(\beta a) \cdot \mathrm{K}_{m}(\beta a)-\mathrm{K}_{m}^{\prime}(\beta a) \cdot \mathrm{I}_{m}(\beta a)}{\mathrm{I}_{m}(\beta a) \cdot \mathrm{K}_{m}(\beta a)-\mathrm{K}_{m}(\beta a) \cdot \mathrm{I}_{m}(\beta a)}
\end{aligned}
$$

Fig. 5の3 本の破線のカーブは, 式 ( 4 ) を解いて求めた 同軸ケーブル部の表面波の分散曲線である .

\section{4 . アンテナによる定存波の共鳴励起}

ここで, Fig.3に示したプローブ頭部の長さ $d$ を変え た実験と，上で述べた表面波の波長入の関係を考えてみ よう.アンンナに加えた角周波数 $\omega$ の電界によって，電 子プラズマ角周波数が $\omega_{\mathrm{p}}$ であるプラズマと誘電体 チューブの界面に表面波を励起する . 帯の波長入は分散 式に従って， $\omega$ と $\omega_{\mathrm{p}}$ の比の值で決まる.例えば，Fig.5 における $m=0$ の実線に注目すると， $\omega / \omega_{\mathrm{p}}=0.7$ のとき $\lambda=16 \mathrm{~mm}$ である .この表面波が , Fig.1においてプロー ブ軸に沿って $z$ の正の方向に進むと,$z=d$ のプローブ端 で反射される.この反射波が $z=0$ までもどってきたと き，ここで再び反射される.なぜならば, $z<0$ の領域

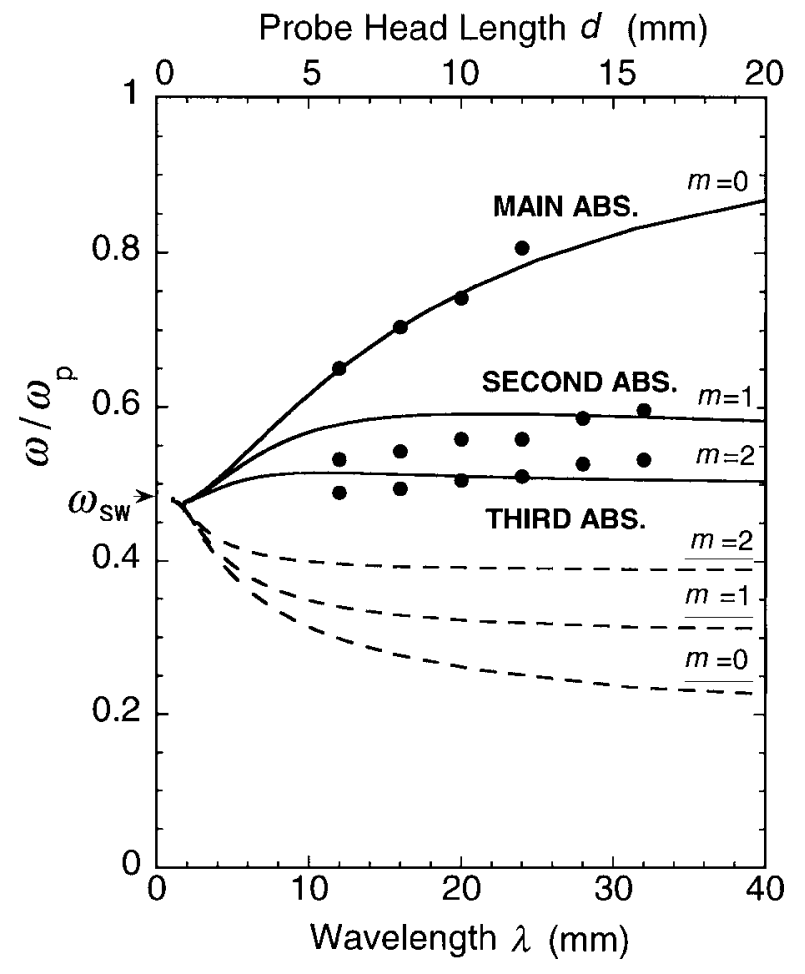

Fig. 5 Solid and dashed lines indicate the dispersion of $\omega / \omega_{\mathrm{p}} \mathrm{vs}$. axial wavelength $\lambda$ calculated for $a=3 \mathrm{~mm}, b=2 \mathrm{~mm}$ and $\varepsilon=3.78$ from Eq. (1) and Eq. (4), respectively. Experimental data of the absorption frequencies in Fig. 3 are plotted assuming $\lambda=2 d$.

(同軸ケーブルのある領域) では $\omega / \omega_{\mathrm{p}}=0.7$ のところに表 面波の解がないからで, $\lambda=16 \mathrm{~mm}$ の表面波の解は $\omega / \omega_{\mathrm{p}}=0.29$ のときに存在する(Fig. 5 の $m=0$ の破線で示 す分散カーブを参照) .このように,アンテナによって励 起された表面波はプローブ頭部 $(0<z<d)$ の両端で反 射され，入射と反射の波が干渉しあって定在波を形成す る。

この状況は,Fig. 6 に示すような円筒キャビティ(空洞 共振器)を外から励振する場合と似ていることに気づく， 今，「プラズマ」という金属壁で囲まれた円筒キャビティ を，左端 $(z=0)$ の壁に設けたアンテナに同軸ケーブル を通してマイクロ波を供給し，励振する場合を考える。 マイクロ波の周波数を高くしていくと, 電磁波の $z$ 方向 の波長 $\lambda$ がキャビティの長さ $d$ の丁度 2 培になると，共 振を起こす．すなわち，電磁波のエネルギーがキャビ ティ内に貯まり，大振幅の定在波が立つ.この $\lambda=2 d$ という共鳴条件からずれると，キャビティに入射したパ ワーは最終的に励起端 $(z=0)$ から同軸ケーブルを通っ て電源側にほとんど反射されてもどってくる．

光の機構をもう少し詳しく見てみよう. $z=0$ の入射” 

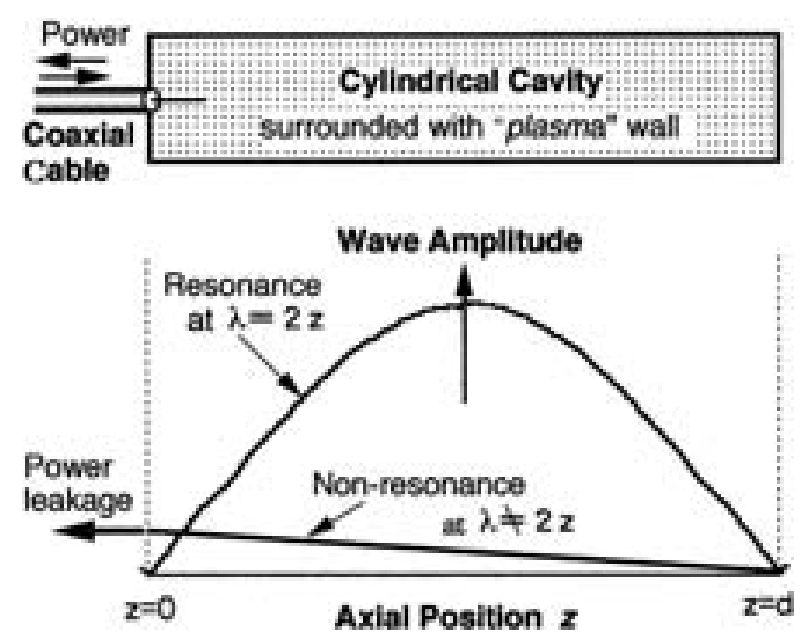

Fig. 6 Cylindrical cavity model of plasma absorption probe excited at different frequencies.

アンテナは, 実は電源側へパワーをもどす“送信”アン テナの役目もする .キャビティからもれて電源側へもど るパワーの大きさは, アンテナ位置 $(z=0)$ での電界 (入射と反射を合成した全電界) の2乗に比例する． $\lambda=2 d$ の共鳴状態のとき, $z=0$ は定在波の節になるの で, 光の電界は非常に小さく, 電磁エネルギーはキャビ ティから外へもれずに蓄積されていき, 強い電界が発生 する.しかし， $\lambda=2 d$ を満たさない非共鳴のときは， $z=0$ では電界が相殺せずに残り，光れが, アンテナで受 信されてキャビティから外へパワーがもれる.このよう なことから，電源 (ネットワークアナライザ) から見た とき, $\lambda=2 d$ となる周波数において共鳴的にパワーの反 射率か下がることになる .このときキャビティに投入さ れたパワーは，光の金属壁の表皮厚さの中でジュール熱 として消費される。

上に述べたキャビティのモデルをプラズマ吸収プロー ブに適用し，表面波の波長入がプローブ頭部の長さ $d$ の 2 倍になる周波数のときに，反射が共鳴的に低下する と仮定する．光して Fig. 3 の $d$ を変化した実験から, 波 長 $\lambda$ と吸収周波数 $\omega / 2 \pi$ を求め, 電子プラズマ周波数 $\omega_{\mathrm{p}}$ はプラズマ振動法によって精度よく求めた電子密度を用 いて計算する.また ,Fig.3の3 本の吸収スペクトル線が $m=0,1,2$ に対応すると考えて，実験值 $\omega / \omega_{\mathrm{p}}$ と $\lambda$ を Fig. 5 にプロットすると, 実線の理論カーブとほぼ合うことが わかる .

例えばアンテナ位置を $d=8 \mathrm{~mm}$ になるように固定し て , ネットワークアナライザの周波数を掃引するという ことは, Fig. 5 において,$\lambda=2 d=18 \mathrm{~mm}$ を通る垂線に
沿って $\omega / \omega_{\mathrm{p}}$ の值を変化することに対応している .光の垂 線が分散カーブと交叉する周波数のところで反射が減る のか観測されることになる .このときプローブに入った マイクロ波パワーは表面波のエネルギーとなり，光の波 の電界で電子が加速されることにより，最終的にプラズ マがパワーを吸収する .

表面波のエネルギーが電子に吸収される機構として は，電子-中性粒子衝突によるジュール加熱のほかに， 無衝突・統計加熱の可能性もある.すなわち, プローブ 近傍の密度勾配を考えると， $\omega / \omega_{\mathrm{p}}$ となるプラズマ共鳴層 が存在し, 乥こに局在する強い電子プラズマ波が励起さ れ，統計的な電子加熱が起こり得る．これらの物理過程 は興味深い問題を含んでいるが，まだ検討が進んでいな い.

\section{5 . 電子密度の測定}

Fig. 5 に示した実験と理論の比較から，プラズマ吸収 プローブで観測される吸収周波数は, プローブ頭部に表 面波の定在波が共鳴的に励起される周波数に対応するこ とが実証された .これをまとめると，無限長の円筒プ ローブに沿う表面波の理論解析に, 実験における長さ $d$ の有限プローブからくる周期境界条件 $(\lambda=2 d)$ をあては めると，吸収がおこる規格化周波数 $\omega / \omega_{\mathrm{p}}$ は, プローブの 形状 $(d, a, b)$ と材質 $\left(\varepsilon_{\mathrm{d}}\right)$ の関数 $F$ として次のように与 えられる 。

$$
\omega / \omega_{\mathrm{p}}=F\left(d, a, b, \varepsilon_{\mathrm{d}}\right)
$$

右辺の関数 $F$ は, 与えられたプローブに対して分散式 (1)を解くことにより得られる .

Fig. 5 は $a=3 \mathrm{~mm}, b=2 \mathrm{~mm}, \varepsilon_{\mathrm{d}}=3.78$ の石英管の場合 に, $d$ の関数として $F$ の計算結果を示したものであ る.したがって，この形状と材質のプローブであれば， Fig. 5 を利用して直ちに電子密度の絶対值を測定するこ とができる.例えば , $d=6 \mathrm{~mm}$ のときに $m=0$ の吸収が 起きるのは, $\omega / \omega_{\mathrm{p}}=0.65$ のときであることが Fig. 5 から 読める.これに電子プラズマ角周波数 $\omega_{\mathrm{p}}=\left(e^{2} n_{\mathrm{e}} /\right.$ $\left.\varepsilon_{0} m_{\mathrm{e}}\right)^{1 / 2}$ の定義を代入して, 電子密度 $n_{\mathrm{e}}$ は次式から得ら れる.

$$
n_{\mathrm{e}}\left[\mathrm{m}^{-3}\right]=2.94 \times 10^{16}\left(f_{\mathrm{abs}}[\mathrm{GHz}]\right)^{2}
$$

ここに $f_{\mathrm{abs}}$ は,$d=6 \mathrm{~mm}$ のプローブで測定した $m=0$ の吸収周波数 $\omega / 2 \pi$ を $\mathrm{GHz}$ 単位で表した数值である.

一方，プローブの形状や材質が F ig. 5の計算例と異な る場合, 測定された吸収周波数 $f_{\mathrm{abs}}$ から電子密度を決定 
するには，次のようないくつかの方法がある .

(i) 理論解析法

使用したプローブの形状と材質に対して，表面波の 分散式(1)を数値計算して解き, Fig. 5 と同樣な分散 カーブを求める. 弚れを用いれば, 式( 6 )の右辺の比 例定数の值を理論的に決めることができる .

\section{(ii) 密度較正法}

式( 5 )からわかるように, 使用するプローブが決ま れば, 吸収周波数は電子密度 $n_{\mathrm{e}}$ の平方根は正比例す る.弚こで, 他の方法で $n_{\mathrm{e}}$ を求めることにより，光の 比例定数を一度決定してしまえば, 兴の後は式( 6 )の ようにして $f_{\mathrm{abs}}$ の 2 乗として $n_{\mathrm{e}}$ を求めることができ る.关の電子密度の較正には,ラングミュアプローブ， プラズマ振動法[1-5]，ママイクロ波干渉法などの方法 が使える．この較正は希ガスの放電プラズマで一度行 えば, 他の反応性プラズマに対しても同じ比例定数が 使える。

(iii) 吸収プローブ測定のみによる方法

上のように理論解析を行ったり，他の密度測定法と 比べたりせずに，吸収プローブの実験だけから電子密 度を決定することも可能である．例えば，Fig.3や Fig. 5 からわかるように,$d$ が小さいときの $m=2,3$ などの高次モードの吸収周波数は, 表面波共鳴周波数 $\omega_{\mathrm{sw}}=2 \pi f_{\mathrm{sw}}$ に非常に近い.したがって，もし光の $f_{\mathrm{sw}}$ が吸収スペクトルから推定できたならば, 式( 3 ) の定義式から次のようにして電子密度が求まる。

$$
n_{\mathrm{e}}\left[\mathrm{m}^{-3}\right]=1.24 \times 10^{16}\left(1+\varepsilon_{\mathrm{d}}\right)\left(f_{\mathrm{sw}}[\mathrm{GHz}]\right)^{2}
$$

実際に誘電体チューブの材質を，石英 $\left(\varepsilon_{\mathrm{d}}=3.78\right)$, パ イレックス $\left(\varepsilon_{\mathrm{d}}=4.84\right)$, アルミナ $\left(\varepsilon_{\mathrm{d}}=9.34\right)$, ジルコニ ア $\left(\varepsilon_{\mathrm{d}}=35\right)$ と変えて測定した所, 式 $(7)$ が良く成立つ ことを確認している．このことを逆に利用すれば，高誘 電率材料のチューブを用いると, 同じ電子密度でも吸収 周波数を下げることができる. 光の結果, ネットワーク アナライザの掃引周波数の上限が $3 \mathrm{GHz}$ のままでもジル コニアを用いれば石英に比へて約 9 倍高い密度まで測定 できるようになる

より正確に $f_{\mathrm{sw}}$ を求めるには次の方法がある. 誘電体 チューブ内の同軸ケーブルとアンテナを動かして Fig.3 のように $d$ を変えてデータをとり, Fig. 5 と同樣に吸収 周波数を $d$ の関数としてプロットする.Fig. 5 の例から わかるように, $m=0$ の測定点を通る直線を引いて $d=0$ を切る周波数を求めれば, 弚の值は $f_{\mathrm{sw}}$ に非常に近 い值となる。
6 .プラズマ吸収プローブの特長と実測例

61 プラズマ吸収プローブの特長

これまで説明してきたように，プラズマ吸収プローブ はプローブ頭部における表面波の励起・吸収を利用して 電子密度を求めるものであるが, 主な特長をまとめると 次のとおりである .

(1)プローブに絶縁膜がついても測定可能

(2)小型で操作が簡単 , 測定精度も高い

(3)プローブ表面は誘電体て覆われているので金属污染 がない

(4)低密度 $\left(10^{14} \mathrm{~m}^{-3}\right)$ から高密度 $\left(10^{19} \mathrm{~m}^{-3}\right)$ まで測定 可能

(5)測定の空間分解能は $\Delta r \sim 2 \mathrm{~mm}$, 時間分解能は $\Delta t$ $\sim 1 \mu \mathrm{s}$

6)放電圧力としては最大約 10T orr 程度まで測定可能 このほかに, 最近の研究から電子温度の測定も可能であ り [14]，理論的に磁場中プラズマへの適用の可能性も示 されている。

62 ラングミュアプローブとの比較

プラズマ吸収プローブで測定した電子密度を他の方法 と比較してみよう．プラズマ振動法を用いて測定した密 度の值と比較して，良い一致が得られることは既に報告 している[8] .また ,シリコン酸化膜エッチング用の磁気 中性線プラズマ装置において , プラズマ吸収プローブで

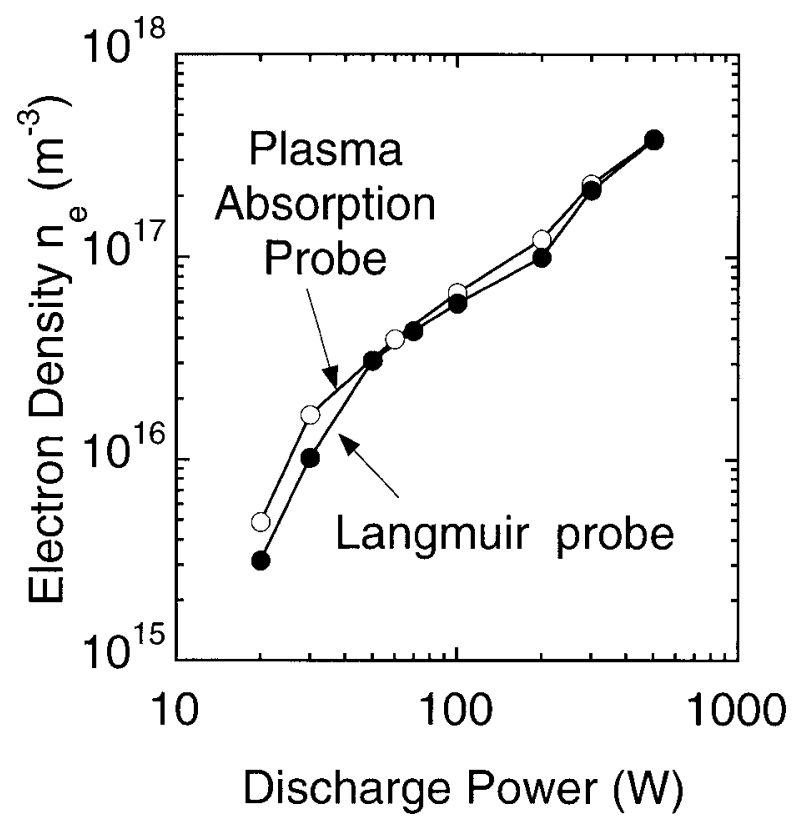

Fig. 7 Comparison of plasma absorption probe data with Langmuir probe data. 

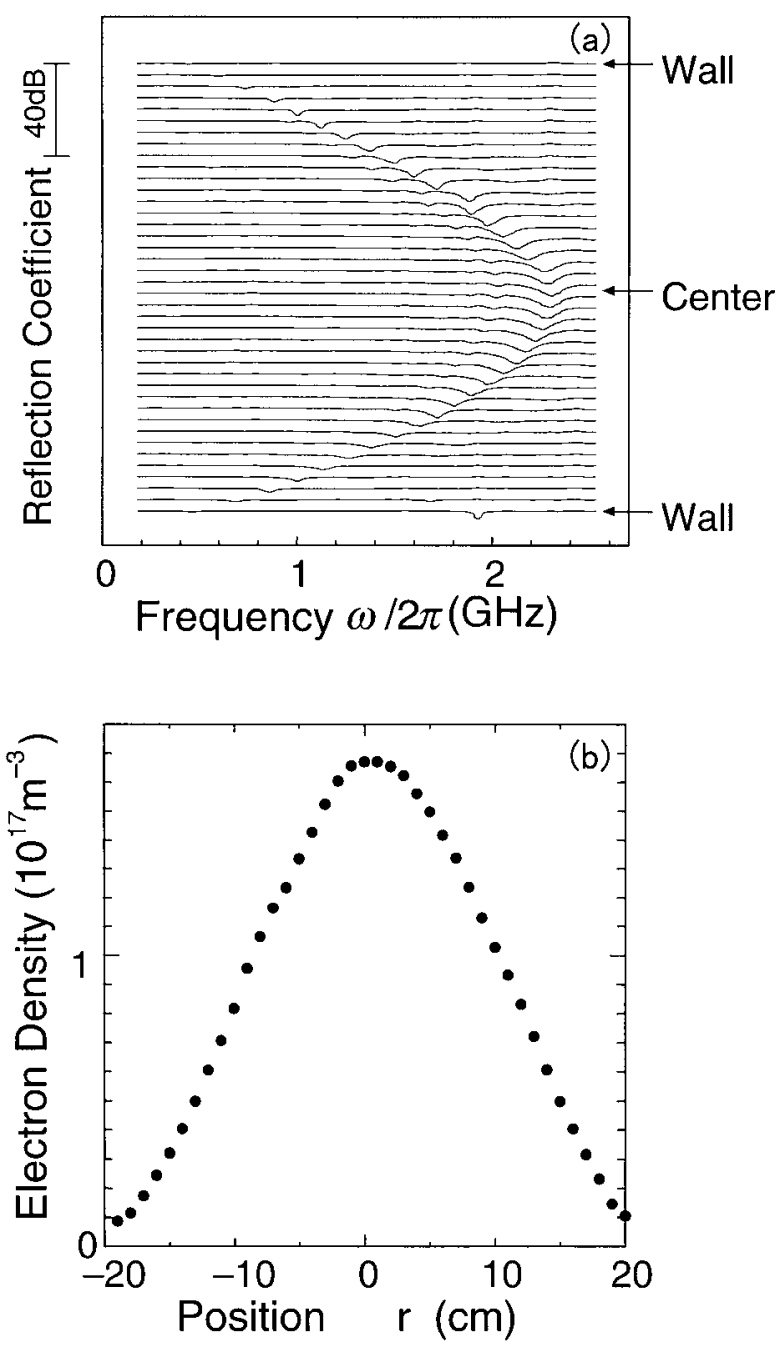

Fig. 8 (a) Absorption frequency spectra for different radial positions, and (b) radial density profile deduced from the spectra in (a) [ by courtesy of Nissin Inc. ].

得た電子密度はマイクロ波干渉計による測定値とほぼ一 致した .F ig. 7 は,アルゴン $10 \mathrm{mT}$ orr の誘導結合プラズ マ (ICP)の放電パワーを変えながら, 円筒ラングミュア プローブのデータからイオンの軌道運動理論に従って求 めた電子密度を, 吸収プローブによる值と比較した例で ある.高密度領域では両者は良い一致を示すが, $10^{16}$ $\mathrm{m}^{-3}$ 以下の低密度領域では相違が見られる.最近，この くい違いは吸収プローブのまわりのシースが厚くなって くるためと判明し，シースを考慮した表面波の解析を行 うと，ラングミュアプローブと良く合ってくることがわ かった[13,14].

\section{3 時間・空間分解測定の例}

プラズマ吸収プローブを動かしながら，容易に電子密 度の空間分布を測定することができる，乥の空間分解能
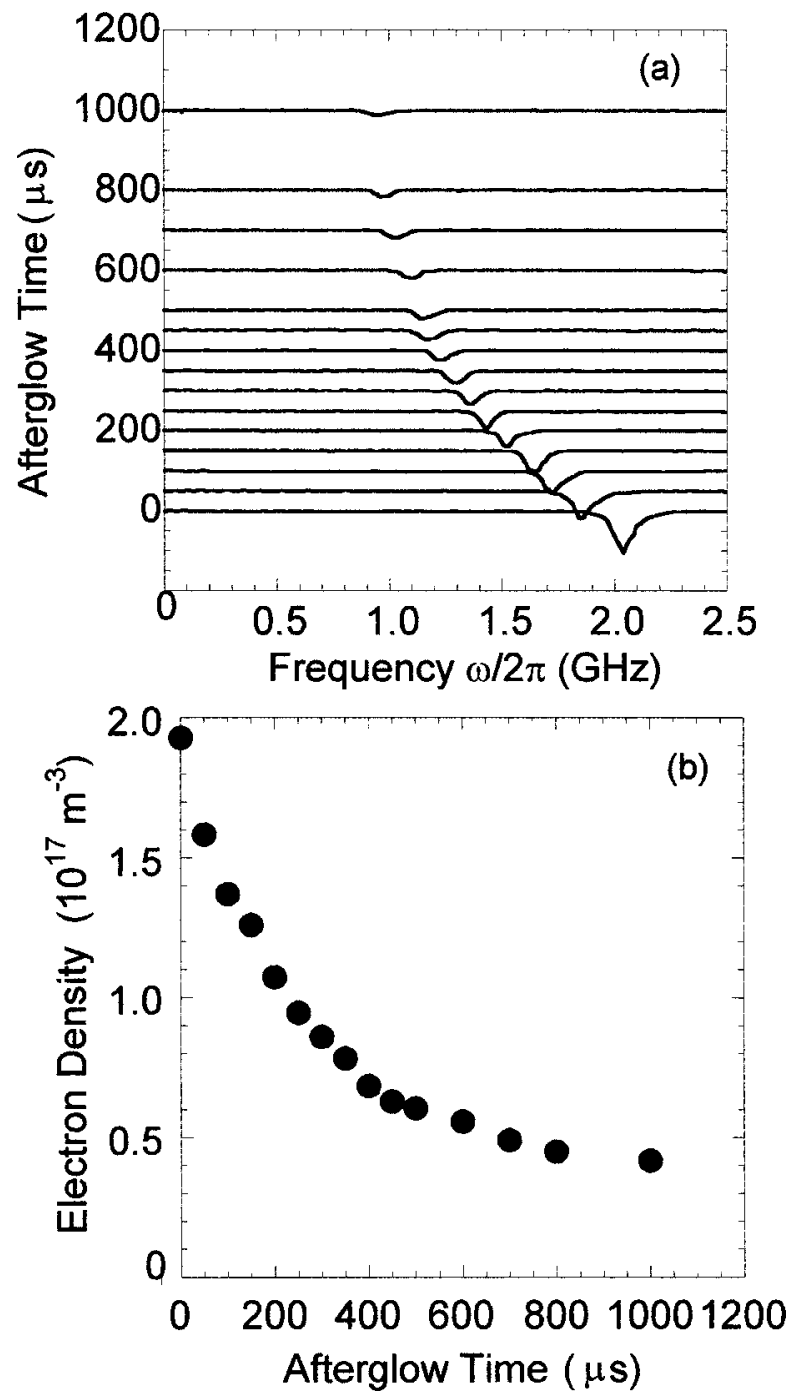

Fig. 9 (a) Absorption frequency spectra for different afterglow times, and (b) temporal decay of electron density in afterglow deduced from the spectra in (a).

は , プローブ頭部の外径 (最小 $2 \mathrm{~mm}$ ) や長さ (約 $5 \mathrm{~mm}$ ) のサイズ程度である .Fig.8は測定例で , 13.56 M Hz の誘 導結合プラズマ(アルゴン $100 \mathrm{mT}$ or r , $150 \mathrm{~W}$ ) のループ アンテナから $20 \mathrm{~cm}$ 離れた中心部での半径方向の密度分 布のデータである.上の (a)図は, プローブ位置を等間隔 に移動させながら，各位置で測定したパワーの反射係数 の周波数スペクトルであり, $m=0$ モードの吸収周波数 が半径とともにシフトするのが見える.式( 6 )のよう に，吸収周波数と電子密度は一義的に結びついているか ら，下の(b)図のように即座に密度分布が得られる。

一方，繰り返しパルス放電のように，一定の周期て繰 り返して変化するプラズマの密度の時間変化を吸収プ ローブで測定することができる . Fig.9は光の一例であ 
り，アルゴン $10 \mathrm{mT}$ orr の $500 \mathrm{~W}$ 誘導結合プラズマを, 光

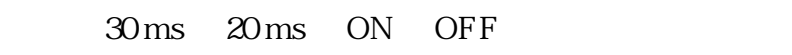
ルス放電を行ったとき,放電OFF後のアフターグロー時 刻における電子密度測定の結果である . (a)図のように， 時間がたつと吸収周波数が低くなり，この周波数を電子 密度に整理しなおしてプロットすると，(b)図のように 電子密度がアフターグロー時間の経過とともに減少して いくのがわかる .この測定では周波数をゆっくり自動掃 引しているために, 時間分解能はあまりよくない . 高分 解能で速い現象を測定するには, 周波数を固定して得ら れる時間変化する出力を, 異なる多くの周波数に対して 集録し，後でデータを整理しなおすことにより，1 $1 \mu \mathrm{sec}$ 程度の時間分解能が得られる。

\section{7 . 材料プロセス用の反応性プラズマへの適用} 半導体プロセスにおいては, 金属不純物の混入はデバ イス特性の著しい劣化をもたらすことが知られている． したがって，ラングミュアプローブやグリッド電極など の金属材料を直接プラズマにさらすことは厳しく制限さ れる．弚の点，プラズマ吸収プローブはFig.1に示すよ うに，すへて石英などの誘電体で覆われているので金属 污染を引き起こす心配がない。

エッチングや CVD などの材料プロセスには, 多樣な 反応性ガスの放電プラズマが用いられる．弚のほとんど の場合に , プラズマと接する固体表面には絶縁性の薄膜 が堆積する．ラングミュアプローブを用いて，メタンプ ラズマやシランプラズマを測定しようとすると, プロー ブ表面とプラズマ容器表面の双方に絶縁膜が成長してく るため, プローブ電流の回路が断たれて測定不能にな る.一方，プラズマ吸収プローブはもともと導電性のな い誘電体チューブでできている．しかも光の厚さは 1 $\mathrm{mm}$ もあるので, 光の上に数 $\mu \mathrm{m}$ 程度の絶縁膜が付着し ても影響はない .これを確かめるために , 外径 $6 \mathrm{~mm} \cdot$ 内径 $4 \mathrm{~mm}$ の石英管製の吸収プローブを，厚さ $50 \mu \mathrm{m}$ のカプトンテープ (ポリイミド, $\varepsilon_{\mathrm{d}}=3.5$ ) で巻いて, 薄 膜付着を模擬して実験を行った．アルゴンの誘導結合プ ラズマのパワーを変えて吸収プローブで電子密度を測定 したところ，Fig.10に示すように , カプトンを巻いても 巻かなくてもほとんど同じ値が得られた .すなわち, 50 $\mu \mathrm{m}$ の厚さまで膜がつても正しく密度測定を行えるこ とがわかる . 石英管上に $\varepsilon_{\mathrm{d}}=2.5$ の別の絶縁層があると

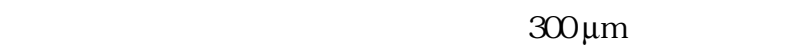
でも変化がなかった . 長期間の使用により, 弚れ以上の 厚い膜が堆積するときは,チャンバークリーニングを $\mathrm{O}_{2}$

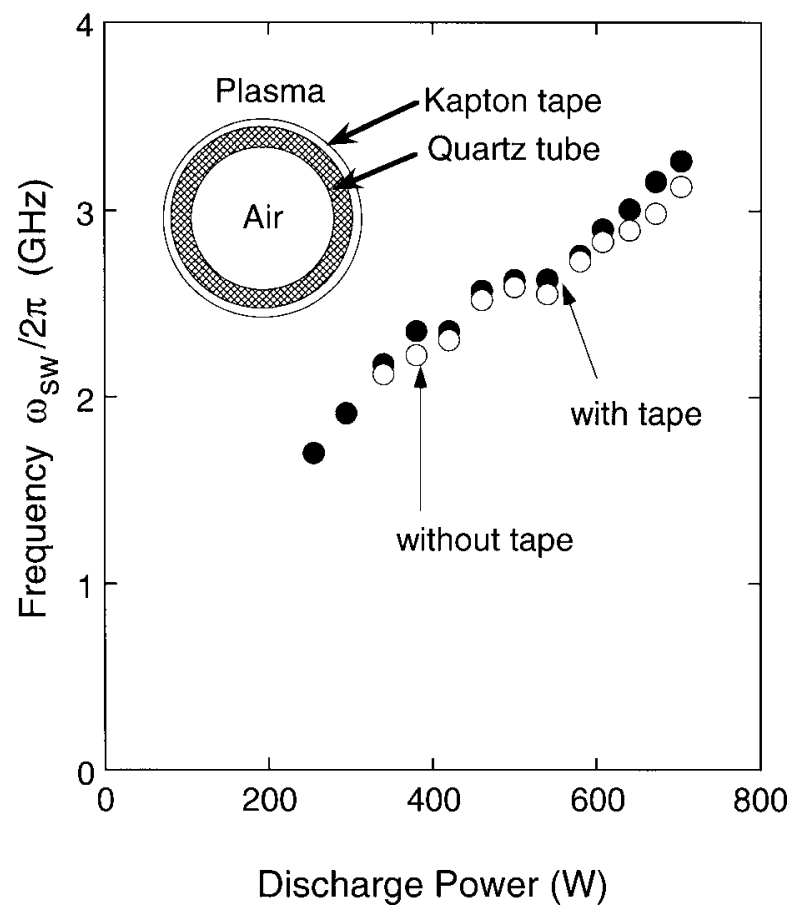

Fig. 10 Surface wave resonance frequency $\omega_{\mathrm{sw}} / 2 \pi$ as a function of ICP discharge power, measured by plasma absorption probe covered with and without $50 \mu \mathrm{m}$ thick Kapton tape.

や NF${ }_{3}$ のプラズマで定期的に行うときに，同時に吸収プ ローブもクリーニングすればよい .

プラズマ吸収プローブはこれまで, フロン , シラン , メタンなどの堆積性の強いガスやハロゲンガス, 酸素な ど，樣々なガスの放電プラズマの測定に用いられてき た .これまでの経験では, プローブ表面の変化のために 測定が難しくなったことはない，唯一，問題が起こると すれば，金属材料のマグネトロンスパッタリングによる 導電膜形成において, プローブ表面にも導電性の薄膜が 堆積する場合であろう．光の膜厚が表皮厚さを超える と, 表面波はシースの影響を強く受け, 波の分散が大き く変化すると予想される .

\section{8.おわりに}

プラズマ吸収プローブの標準的なシステムとデータ解 析法について解説した . このシステムは, プローブの本 体部分を手作りで用意し，市販のネットワークアナライ ザと組み合わせて自分で構築することができる．しか し , ネットワークアナライザには本測定に必要のない 樣々な機能を持たせており，高価である．最近，電子密 度測定に特化した回路系と各種プローブ本体および光の 
駆動機構，データ解析ソフトを用意したシステムが，株 式会社ニッシンから「プラズマ密度計」として市販され ている (詳細は http://www.cgc.co.jp/nissin/) .

プラズマ吸収プローブには, 今後, さらなる高精度化， 高感度化, 汎用化に向けて改良できる点がいくつか残さ れている. 弚の主な課題と開発途上の情報をまとめると 次のとおりである .

(1)高感度化 : 石英管でアンテナを覆う標準型プローブか ら，アンテナ線を直接プラズマにさらす高感度型プ ローブにすることにより，吸収が10倍程度強くなり， 10T orr を越える高圧力まで測定可能となる [14] .

(2)高精度化 : 通常はプローブ周辺のシースは無視できる が, $10^{16} \mathrm{~m}^{-3}$ をきるような低密度ではシースを考慮し たデータ解析が必要になる.特に, 高感度型プローブ では重要になる $[13,14]$.

(3)汎用化 : 上記の高感度型プローブを利用して, 電子温 度も同時に測定できる[14]．また ,これまでは無磁場 を想定してきたが , 有磁場プラズマでも使えるような プローブ形状とデータ解析法の開発を進めている．

(4)生産装置のモニタ: プラズマプロセスの研究開発で は, プローブを動かして精度よく分布を測る必要があ るが, 量産現場では, 壁近くのプローブで, プラズマ の変動を敏感に検知することか望ましい. 現在, 兴の ようなシステムを開発中である.

(5) $S / N$ 比の改善 : 誘導結合プラズマや表面波プラズマの ような低ガス圧・高密度プラズマの測定は容易であ る.しかし, 高ガス圧・低密度プラズマである容量結 合型プラズマの測定は, 特に大電力放電の場合は難し い. 兴の原因は, プラズマ電位が高周波で強く振動し ているためであり，吸収ピークの周りに放電周波数を 基本波とする多数のサイドバンドか現れる .

この解説を機に，できるだけ多くの方々がプラズマ吸収 プローブに関心をもち，一度試してみようかと思ってい ただければ幸いである、最後に，このプローブを共同で
開発している中村圭二氏 (中部大) , 豊田直樹氏 (ニッシ ン）と，ご支援いただいた株式会社ニッシンに謝意を表 します．

\section{参考文献}

[ 1 ] T.Shir akaw a and H. Sugai, Jpn. J. A ppl. Phys. 32,5129 (1993).

[ 2 ] T.H.A hn,K.Nakamuraand H.Sugai,Jpn.J.A ppl.Phys. 34, L1405 (1995).

[ 3 ] M.Goto,H.T oy oda,M .Kitagaw a,T .Hir ao and H.Sugai, Jpn. J. A ppl. Phys. 36, 3714 (1997).

[ 4 ] A .Schw abedissen,E.C.Benck and J.R.Roberts,Plasma Sources Sci. T echnol. 7, 119 (1998).

[ 5 ] A . Schw abedissen, C. Soll, A . Brockhaus and J. Engemann, Plasma Sources Sci. T echnol. 8, 440 (1999).

[6 ] M. Deguchi and R. Itatani, Jpn. J. A ppl. Phys. 37, 970 (1998).

[ 7 ] N. St. Braithwaite, J.P. Booth and Cunge, Plasma Sources Sci. T echnol. 5, 677 (1996).

[ 8 ] H.Kokura,K.Nakamura, I.V.Ghanashev and H.Sugai, Jpn. J. A ppl. Phy s. 38, 5262 (1999).

[ 9 ] N.T oy oda, S. Nankou and H.Sugai.Proc. Int. Conf. Phenomena in Ionized Gases, Nagoy a, 2001, V ol. 3, p.205.

[10] K. Kinoshita, H. Kokura, N. T oy oda, S. Nankou et al., Proc. Int. Conf. Phenomena in Ionized Gases, Nagoy a, 2001, V ol. 2, p.77.

[11] K. Ohata, K. Mizuno, K. Nakamura and H. Sugai, Proc. Int. Conf. Phenomena in Ionized Gases, Nagoy a, 2001, $\mathrm{V}$ ol. 4, p.275.

[12] K. Nakamura, N. Kasuy a, S. Nankou, N. T oy oda and H. Sugai, Proc. Int. Conf. Phenomena in Ionized Gases, Nagoy a, 2001, V ol. 4, p.273.

[13] K. Nakamura, M. Ohata and H. Sugai, Proc. Joint Conf. ESCAMPIG-16 and ICRP-5, Grenoble,2002, V ol.2,p.379.

[14] K. Nakamura, M. Ohata and H. Sugai, to be published in J.V ac. Sci. T echnol. A .

[15] 菅井秀郎編著 : プラズマエレクトロニクス (オーム 社, 2000) p.123. 